\title{
ANALISIS KOMPOSISI GAS BUANG AKIBAT PERUBAHAN MAIN JET NOZZLE PADA SISTEM KARBURATOR MESIN
}

\author{
Bernadi Ksatria Putra'), Abrar Riza ${ }^{2)}$ dan Asrul Aziz ${ }^{3)}$ \\ Program Studi Teknik Mesin Universitas Tarumanagara, Jakarta \\ e-mail: bernad1.blueocean@gmail.com
}

\begin{abstract}
Fuel entering through the main jet nozzle, affects engine performance and the composition of the exhaust gas is produced. Research the composition of the exhaust gases in machines otto one cylinder done with experimental method. The purpose of this study was to obtain the characteristics of the engine with exhaust gas analysis method. This research done with varying size main jet nozzle and varying the engine rotation every $400 \mathrm{rpm}$. Data processing the results of testing includes a comparison of the composition of the exhaust gases is $\mathrm{HC}, \mathrm{CO}_{2}, \mathrm{CO}, \mathrm{O}_{2}, \mathrm{AFR}$, and the temperature of the exhaust gases. Then calculate the enthalpy of combustion for each main jet nozzle. The composition of the exhaust gases are best obtained from the main jet nozzle GX 160 which has the highest $\mathrm{CO}_{2}$ value of 20\%, with the lowest CO value of $1.26 \%$ and the largest combustion enthalpy value with the value of $264.769 \mathrm{~kJ}$. From the analysis can be known that the burning of the main jet nozzle GX 160 approaching the stoichiometric combustion.
\end{abstract}

Keywords: main jet nozzle, exhaust gas, engine rotation speed, stoichiometric combustion.

\section{PENDAHULUAN}

Kemajuan teknologi pada dewasa ini berkembang begitu cepat, terutama di bidang transportasi kendaraan. Banyaknya kendaraan berdampak negatif terhadap lingkungan sekitar, karena pembakaran bahan bakar baik itu menggunakan bensin, solar, dan lain-lain pastinya menghasilkan gas buang. Gas buang itu terdiri atas zat yang tidak beracun seperti nitrogen $\left(\mathrm{N}_{2}\right)$, karbon dioksida $\left(\mathrm{CO}_{2}\right)$, dan uap air $\left(\mathrm{H}_{2} \mathrm{O}\right)$, dan zat beracun seperti karbon monoksida (CO), hidrokarbon (HC), oksida nitrogen (NOx), sulfur oksida (SOx), zat debu timbal (Pb), dan partikulat. Jika gas beracun ini melebihi ambang batas aman, bisa membahayakan kesehatan manusia yang menghirupnya. Ini juga bisa menyebabkan efek pemanasan global dan hujan asam. Pembakaran yang terjadi di dalam ruang motor bakar dipengaruhi oleh tiga faktor yaitu adanya oksigen, bahan bakar, dan panas (heat). Tanpa adanya ketiga faktor itu pembakaran tidak mungkin terjadi.

Pada mesin otto, bahan bakar dimasukkan dengan dua cara ada yang menggunakan karburator dan ada yang menggunakan injeksi bahan bakar. Karburator digunakan untuk mencampur bahan bakar dengan udara. Jumlah bahan bakar yang masuk ini dipengaruhi oleh ukuran lubang (diameter) di dalam main jet nozzle. Semakin besar ukuran nosel nya maka akan semakin banyak bahan bakar yang masuk ke dalam karburator dan ini akan mempengaruhi proses pembakaran yang terjadi. Dari gas buangnya kita bisa menganalisis bagaimana proses pembakaran yang terjadi, bagaimana perbandingan campuran udara dengan bahan bakar, sehingga bisa mendekati kondisi pembakaran sempurna. Dari uji emisi juga kita bisa mengetahui kinerja mesin tersebut.

Campuran bahan bakar dan udara di dalam karburator dipengaruhi oleh main jet nozzle, penggunaan nozzle yang tidak tepat akan mengganggu dan mengurangi performa mesin. Performa mesin ini bisa diwakilkan melalui gas buang yang dihasilkannya. Maka dibutuhkan pemilihan main jet nozzle yang sesuai dengan kebutuhan yang akan digunakan, ada tiga main jet nozzle yang akan digunakan, main jet nozzle GX $140 \leq$ main jet nozzle GX $160 \leq$ main jet nozzle GX 200. Diameter main jet nozzle ini mempengaruhi gas buang dan kinerja mesin. Konsep pembakaran menyatakan bahan bakar harus berfase uap. Semakin banyak uap yang terbentuk semakin baik pembakaran yang terjadi, karena banyak yang teruapkan akan berbanding lurus dengan keberhasilan pembakaran. 


\section{PERUMUSAN MASALAH}

Dilakukan pengujian kemudian menganalisis secara eksperimen dan teoritis untuk mengetahui pengaruh main jet nozzle GX 140, GX 160 dan GX 200 terhadap gas buang yang dihasilkan. Data gas buang yang diperoleh akan menunjukkan keberhasilan pembakaran yang terjadi di dalam motor bakar. Tujuan dari penelitian ini adalah mendapatkan karakteristik emisi dari hasil gas buang pembakaran sebagai salah satu metode untuk mendapatkan unjuk kerja mesin atau yang dapat mewakili unjuk kerja mesin tersebut.

Dalam penelitian ini, batasan masalah yang digunakan yaitu:

a. Pada penelitian ini dilakukan pada motor bakar 4 langkah, volume silinder 160 cc dengan menggunakan motor Honda GX 160.

b. Bahan bakar yang digunakan hanya menggunakan bahan bakar bensin (Premium) dengan volume fuel gauge yang digunakan sebanyak $8 \mathrm{~mL}$.

c. Mengubah putaran mesin otto.

d. Variasi main jet nozzle yang digunakan yaitu main jet nozzle dari mesin GX 140, GX 160, dan GX 200.

e. Menganalisis gas buang yang didapat, meliputi temperatur, gas $\mathrm{HC}$ sisa, $\mathrm{CO}, \mathrm{CO}_{2}, \mathrm{O}_{2}$ sisa, air fuel ratio (AFR), dan lambda yang diperoleh, hal ini terkait keterbatasan alat gas analyzer yang digunakan.

\section{KAJIAN PUSTAKA}

Motor bakar adalah salah satu jenis mesin konversi energi yang banyak dipakai sebagai penggerak kendaraan (otomotif) atau sebagai penggerak peralatan industri. Motor bakar memanfaatkan energi kalor dari proses pembakaran menjadi energi mekanik. Pada motor bakar torak energi dari pembakaran bahan bakar yang menghasilkan energi dorong pada piston, kemudian piston bergerak secara translasi dan diubah menjadi energi putaran dengan mengunakan mekanisme poros engkol [1]. Energi panas diperoleh dari pembakaran bahan bakar dengan udara yang terjadi pada ruang bakar (combustion chamber) dengan bantuan bunga api yang berasal dari percikan busi untuk menghasilkan gas pembakaran [2].

Pada siklus aktual pada mesin Otto, fluida kerjanya adalah campuran bahan bakar dan udara, jadi ada proses pembakaran untuk sumber panas. Pada siklus ini kalor merupakan hasil dari proses pembakaran. Untuk langkah hisap tekanan lebih rendah dibanding dengan langkah buang. Proses kompresi dan ekspansi tidak pada kondisi adiabatis karena pada proses ini terdapat kerugian panas yang keluar ruang bakar. Proses pembakaran dari penyalaan busi (ignition) sampai akhir pembakaran. Untuk lebih jelasnya bisa dilihat diagram p-V pada Gambar 1.

Karburator merupakan komponen motor bakar yang berfungsi mengatur campuran perbandingan udara dan bahan bakar menjadi kabut sebelum masuk ke silinder. Selain itu, karburator dapat menambah atau mengurangi jumlah campuran bahan bakar dan udara sesuai dengan kecepatan dan beban mesin yang berubah-ubah.

Prinsip kerja karburator berdasarkan hukum-hukum fisika seperti Kontinuitas dan Bernauli. Jumlah tekanan (P) pada sepanjang tabung alir (yang diameternya sama) juga akan selalu tetap. Jika terdapat bagian dari tabung alir/pipa yang diameternya diperkecil maka dapat diperoleh kesimpulan bahwa bila campuran bensin dan udara yang mengalir melalui suatu tabung yang luas penampangnya mengecil (diameternya diperkecil) maka kecepatannya akan bertambah sedangkan tekanannya akan menurun. Prinsip hukum di atas tersebut dipakai untuk mengalirkan bensin dari ruang pelampung karburator dengan memperkecil suatu diameter dalam karburator. Pengecilan diameter atau penyempitan saluran ini disebut dengan venturi. Dari Gambar 2. dapat dilihat bahwa bensin akan terhisap dan keluar melalui venturi dalam bentuk butiran-butiran kecil karena saat itu kecepatan udara dalam venturi lebih tinggi namum tekanannya lebih rendah dibanding dalam ruang bensin yang berada di bagian bawahnya (fluida akan mengalir dari tekanan tinggi ke tekanan rendah). 


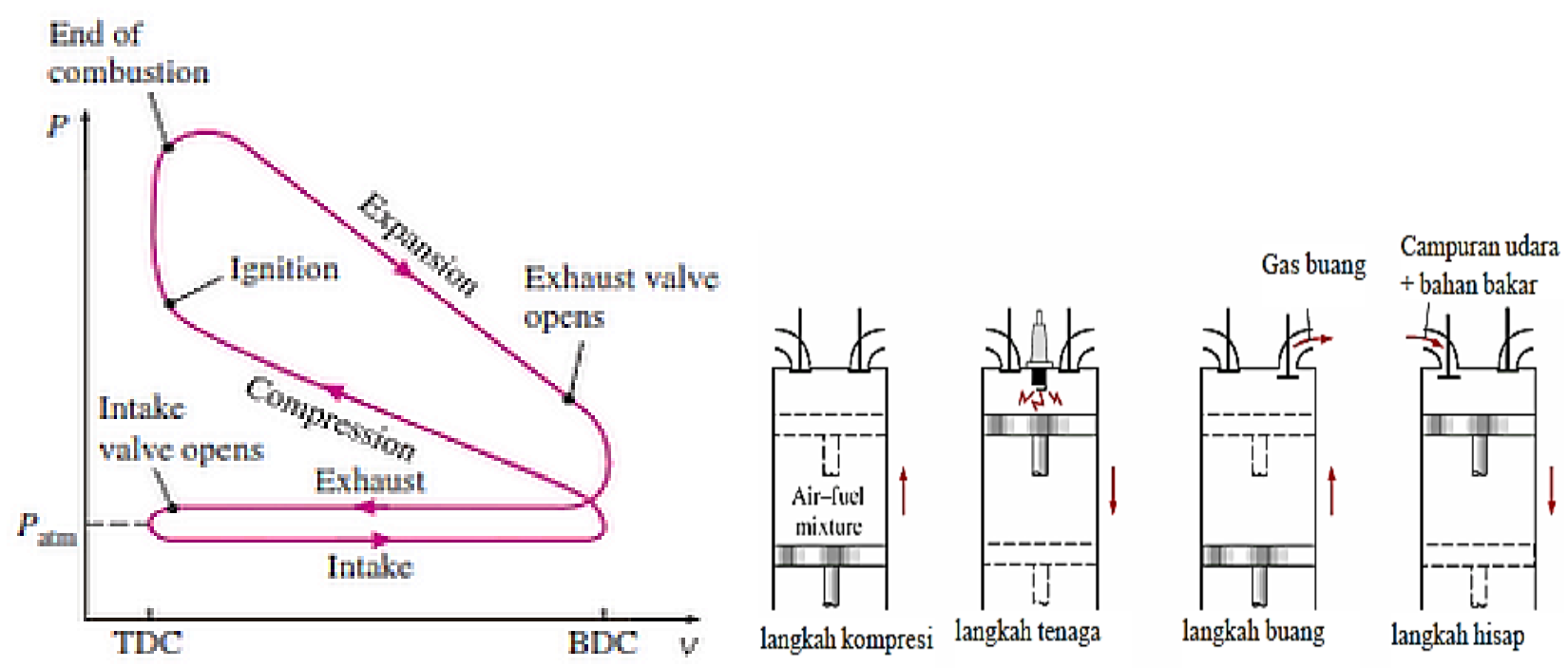

Gambar 1. Siklus Aktual Otto [1]

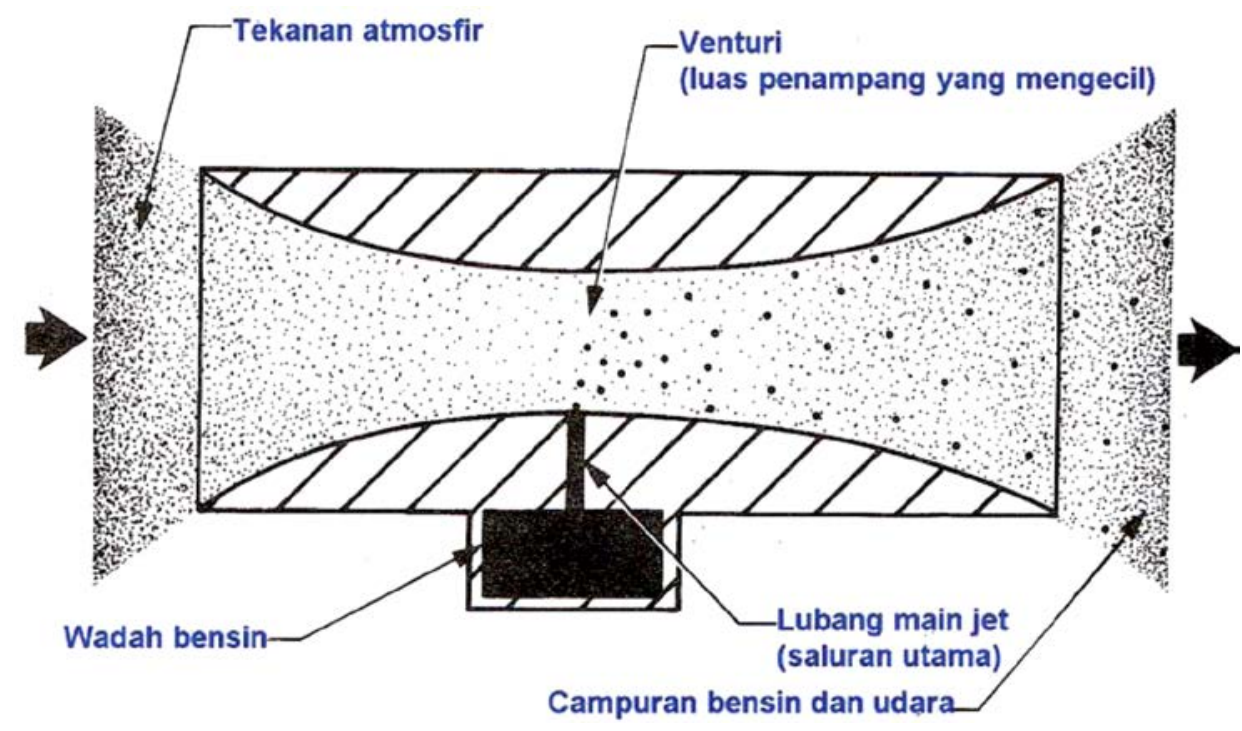

Gambar 2. Prinsip Kerja Venturi [3]

Secara umum hanya terdapat tiga unsur yang penting di dalam bahan bakar, yaitu karbon, hidrogen, dan sulfur (belerang). Dalam proses pembakaran, energi kimia diubah menjadi energi dalam bentuk panas dimana pada setiap pembakaran selalu dihasilkan gas sisa hasil dari proses pembakaran yang dinamakan gas buang. Pembakaran (combustion) bisa terjadi jika ada tiga komponen berikut yaitu oksigen, bahan bakar (fuel) dan panas. Jika salah satu komponen tersebut tidak ada maka tidak akan muncul reaksi pembakaran. Secara umum proses pembakaran dapat dilukiskan sebagai berikut:

$$
\text { Bahan bakar }+ \text { Oksigen }+ \text { Panas } \longrightarrow \text { Pembakaran } \longrightarrow \text { Energi + Gas Buang }
$$

Bensin terdiri dari oktana $\left(\mathrm{C}_{8} \mathrm{H}_{18}\right)$ dan heptana $\left(\mathrm{C}_{7} \mathrm{H}_{16}\right)$. Persamaan reaksi pembakaran sempurna adalah:

$$
\begin{aligned}
& 2 \mathrm{C}_{8} \mathrm{H}_{18}+25 \mathrm{O}_{2} \longrightarrow 16 \mathrm{CO}_{2}+18 \mathrm{H}_{2} \mathrm{O} \\
& \mathrm{C}_{7} \mathrm{H}_{16}+11 \mathrm{O}_{2} \longrightarrow 7 \mathrm{CO}_{2}+8 \mathrm{H}_{2} \mathrm{O}
\end{aligned}
$$


Jika udara itu terdiri dari 21\% oksigen dan 79\% nitrogen maka persamaan kimianya akan menjadi:

$$
\begin{aligned}
& \mathrm{C}_{8} \mathrm{H}_{18}+12,5 \mathrm{O}_{2}+12,5(3,76) \mathrm{N}_{2} \longrightarrow 8 \mathrm{CO}_{2}+9 \mathrm{H}_{2} \mathrm{O}+47 \mathrm{~N}_{2} \\
& \mathrm{C}_{7} \mathrm{H}_{16}+11 \mathrm{O}_{2}+11(3,76) \mathrm{N}_{2} \longrightarrow 7 \mathrm{CO}_{2}+8 \mathrm{H}_{2} \mathrm{O}+41,36 \mathrm{~N}_{2}
\end{aligned}
$$

Jumlah udara minimum yang dibutuhkan untuk pembakaran dari suatu bahan bakar dinamakan "udara teoritis". Tetapi dalam kenyataannya sangat sulit untuk mencapai pembakaran yang sempurna dengan udara teoritis. Pembakaran seperti ini dinamakan pembakaran sempurna. Pembakaran sempurna adalah pembakaran dimana semua unsur yang dapat terbakar di dalam bahan bakar membentuk gas $\mathrm{CO}_{2}$, dan $\mathrm{H}_{2} \mathrm{O}$, sehingga tak ada lagi bahan bakar yang tersisa [4].

Pembakaran dengan campuran kaya akan menghasilkan hidrokarbon (HC) sisa, karena bahan bakar yang tidak terbakar dan keluar menjadi gas mentah. Bahan bakar terpecah karena reaksi panas berubah menjadi gugusan HC lain yang keluar bersama gas buang [7]:

$\mathrm{C}_{8} \mathrm{H}_{18} \longrightarrow \mathrm{H}+\mathrm{C}+\mathrm{H}$

Secara umum reaksi kimia pembakaran bahan bakar dalam kondisi campuran kaya (bahan bakar berlebih) adalah:

$\mathrm{C}_{8} \mathrm{H}_{18}+\mathrm{O}_{2}+3,76 \mathrm{~N}_{2} \longrightarrow \mathrm{CO}_{2}+\mathrm{H}_{2} \mathrm{O}+3,76 \mathrm{~N}_{2}+\mathrm{CO}+\mathrm{HC}$ sisa $+\mathrm{H}_{2}$

Sebaliknya pembakaran campuran miskin (jumlah udara berlebih) akan menghasilkan udara berlebih juga (excess air). Pembakaran yang tidak sempurna dalam mesin menyisakan oksigen ke udara. Oksigen yang tersisa ini semakin kecil bila mana pembakaran terjadi makin sempurna. Secara umum reaksi kimia untuk pembakaran bahan bakar dalam kondisi campuran miskin (udara berlebih) adalah:

$\mathrm{C}_{8} \mathrm{H}_{18}+\mathrm{O}_{2}+3,76 \mathrm{~N}_{2} \longrightarrow \mathrm{CO}_{2}+\mathrm{H}_{2} \mathrm{O}+3,76 \mathrm{~N}_{2}+\mathrm{O}_{2}$ sisa

Perubahan entalpi pada pembentukan 1 mol zat langsung dari unsur-unsurnya disebut entalpi molar pembentukan atau entalpi pembentukan. Jika pengukuran dilakukan pada keadaan standar (298 K, $1 \mathrm{~atm}$ ) dan semua unsur-unsurnya dalam bentuk standar, maka perubahan entalpinya disebut entalpi pembentukan standar $\left(\Delta \mathrm{h}_{\mathrm{f}}{ }^{0}\right)$. Entalpi pembentukan dinyatakan dalam kilojoule per mol $\left(\mathrm{kJ} \mathrm{mol}^{-1}\right)$. Untuk unsur yang mempunyai bentuk alotropi, bentuk standarnya ditetapkan berdasarkan pengertian tersebut. Misalnya, karbon yang dapat berbentuk intan, grafit, atau fulleren, bentuk standarnya adalah grafit, karena grafit adalah bentuk karbon yang paling stabil pada $298 \mathrm{~K}, 1 \mathrm{~atm}$.

Perubahan entalpi pada pembakaran sempurna 1 mol suatu zat yang diukur pada $298 \mathrm{~K}, 1$ atm disebut entalpi pembakaran standar dan dinyatakan dengan $\Delta \mathrm{h}_{\mathrm{C}}{ }^{\circ}$ (standard enthalphy of combustion). Entalpi pembakaran juga dinyatakan dalam $\mathrm{kJ} \mathrm{mol}^{-1}$. Entalpi pembakaran suatu zat dapat juga ditentukan berdasarkan data entalpi pembentukan zat pereaksi dan produknya. Dalam hal ini, zat pereaksi dianggap terlebih dahulu terurai menjadi unsur-unsurnya, kemudian unsur-unsur itu bereaksi membentuk zat produk. Sebagai contoh entalpi pembakaran karbon (C) sama dengan reaksi pembentukan karbon dioksida $\left(\mathrm{CO}_{2}\right)$.

Rumus entalpi pembakaran (enthalphy of combustion):

$\mathrm{h}_{\mathrm{RP}}=\mathrm{h}_{\mathrm{P}}-\mathrm{h}_{\mathrm{R}}$ 
Dengan:

$\mathrm{h}_{\mathrm{RP}}$ : Entalpi pembakaran

$\mathrm{h}_{\mathrm{P}} \quad$ : Entalpi produk

$\mathrm{h}_{\mathrm{R}} \quad$ : Entalpi reaktan

Secara umum untuk reaksi:

$$
\begin{aligned}
& m \mathrm{AB}+n \mathrm{CD} \longrightarrow p \mathrm{AD}+q \mathrm{CB} \quad \Delta \mathrm{h}_{\mathrm{c}}{ }^{0}=\text { ? } \\
& \Delta \mathrm{h}_{\mathrm{C}}{ }^{0}=\left[p \times \Delta \mathrm{h}_{\mathrm{f}}{ }^{0} \mathrm{AD}+q \times \Delta \mathrm{h}_{\mathrm{f}}{ }^{0} \mathrm{CB}\right]-\left[m \times \Delta \mathrm{h}_{\mathrm{f}}{ }^{0} \mathrm{AB}+n \times \Delta \mathrm{h}_{\mathrm{f}}{ }^{0} \mathrm{CD}\right] \\
& \Delta \mathrm{h}_{\mathrm{C}}{ }^{\mathrm{o}}=\Sigma \mathrm{n}_{\mathrm{P}} \Delta \mathrm{h}_{\mathrm{f}}{ }^{\mathrm{o}}(\text { produk })-\Sigma \mathrm{n}_{\mathrm{R}} \Delta \mathrm{h}_{\mathrm{f}}{ }^{\mathrm{o}} \text { (pereaksi) }
\end{aligned}
$$

Kita bisa menghitung nilai kalor yang dibebaskan pada pembakaran $8 \mathrm{~mL}$ bensin (volume bensin yang digunakan dalam flow gauge adalah $8 \mathrm{~mL}$ ), diasumsikan bensin hanya terdiri atas isooktana $\mathrm{C}_{8} \mathrm{H}_{18}$, massa jenis isooktana diketahui yaitu $0,703 \mathrm{~kg} \mathrm{~L}^{-1}$. ( $\left.\mathrm{Ar} \mathrm{H}=1 ; \mathrm{C}=12\right)$. Nilai entalpi pembakaran untuk isooktan yaitu $-47893 \mathrm{~kJ} \mathrm{~kg}^{-1}$ (tanda - artinya kalor dibebaskan, reaksinya merupakan reaksi eksoterm).

Massa dari $8 \mathrm{~mL}$ liter bensin adalah $=0,008 \times 0,703 \mathrm{~kg} \mathrm{~L}^{-1}=5,624 \times 10^{-3} \mathrm{~kg}$

Jadi, kalor yang dibebaskan pada pembakaran $8 \mathrm{~mL}$ bensin adalah 5,624 x $10^{-3} \mathrm{~kg}$ x 47893 $\mathrm{kJ} \mathrm{kg}^{-1}=269,350232 \mathrm{~kJ}$.

\section{METODOLOGI PENELITIAN}

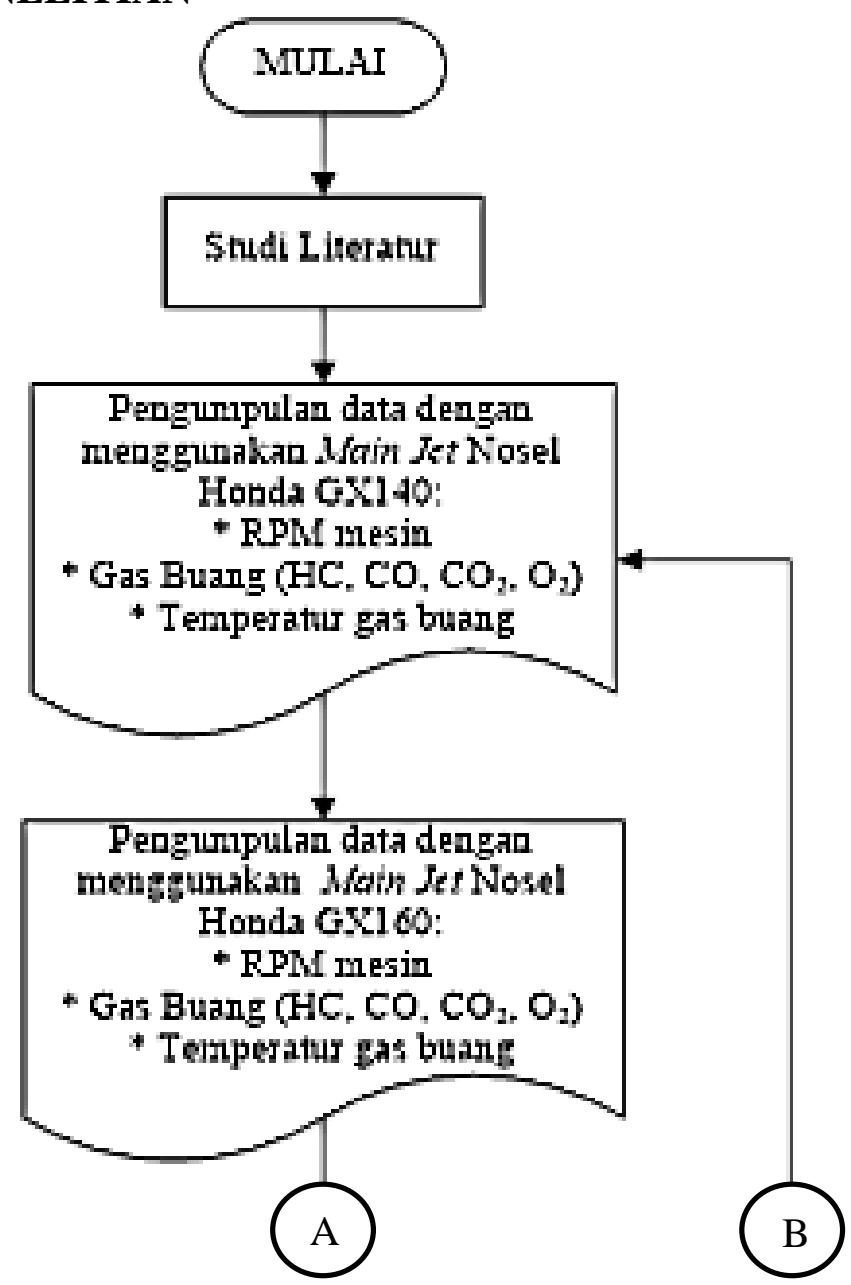

Gambar 3.Diagram alir penelitian 
Gambar 3. Diagram alir penelitian

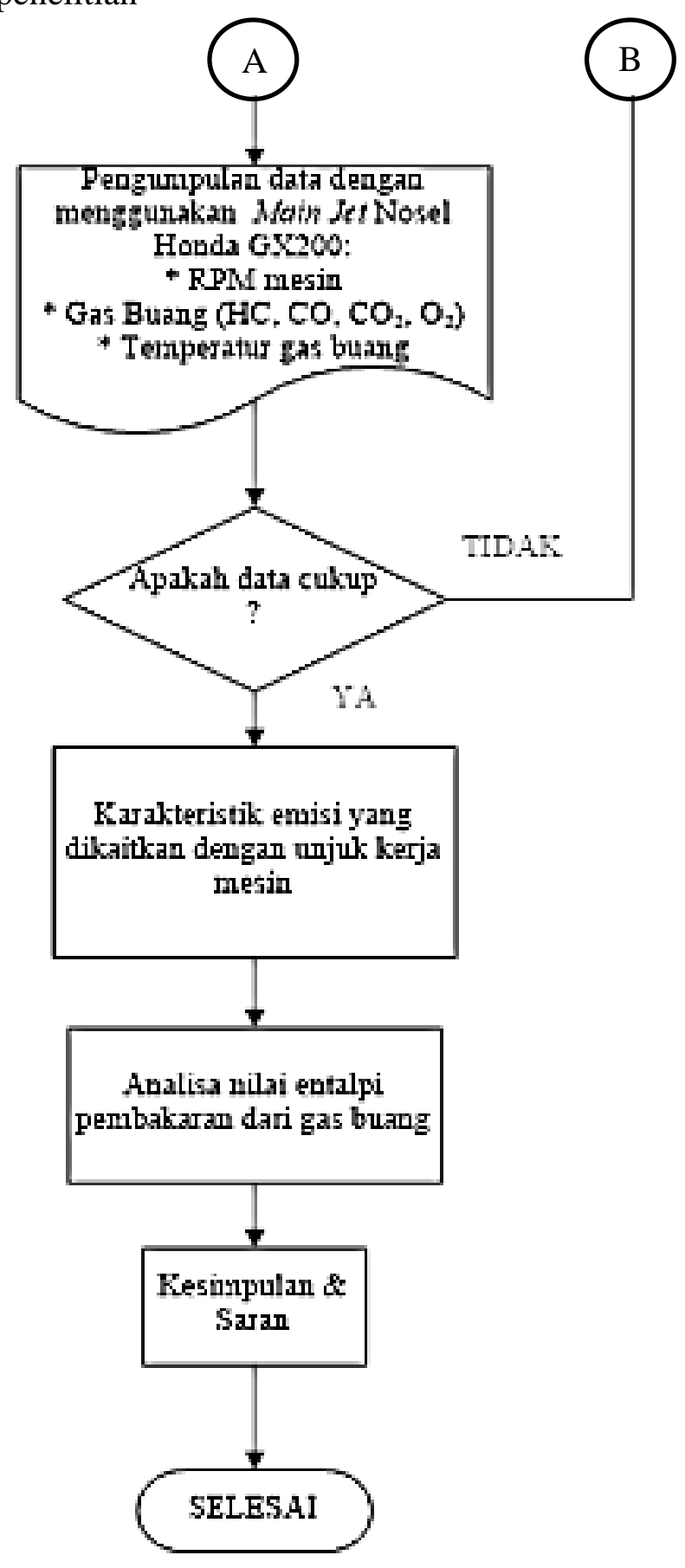

Penelitian dilakukan di Laboratorium Prestasi Mesin Jurusan Teknik Mesin, Universitas Tarumanagara dengan menggunakan mesin Honda GX 160. Dalam kegiatan eksperimental ini bahan yang digunakan adalah bahan bakar jenis premium dengan nilai oktan 88. Bahan bakar premium yang digunakan sejak awal pengujian hingga akhir pengujian diusahakan sebisa mungkin memiliki kualitas dan nilai kalor yang sama, oleh karena itu maka pembelian premium hanya dilakukan satu kali dan digunakan dari awal hingga akhir eksperimental.

Peralatan yang digunakan pada kegiatan eksperimental ini adalah mesin motor bakar merek Honda, dengan tipe Honda GX 160. 


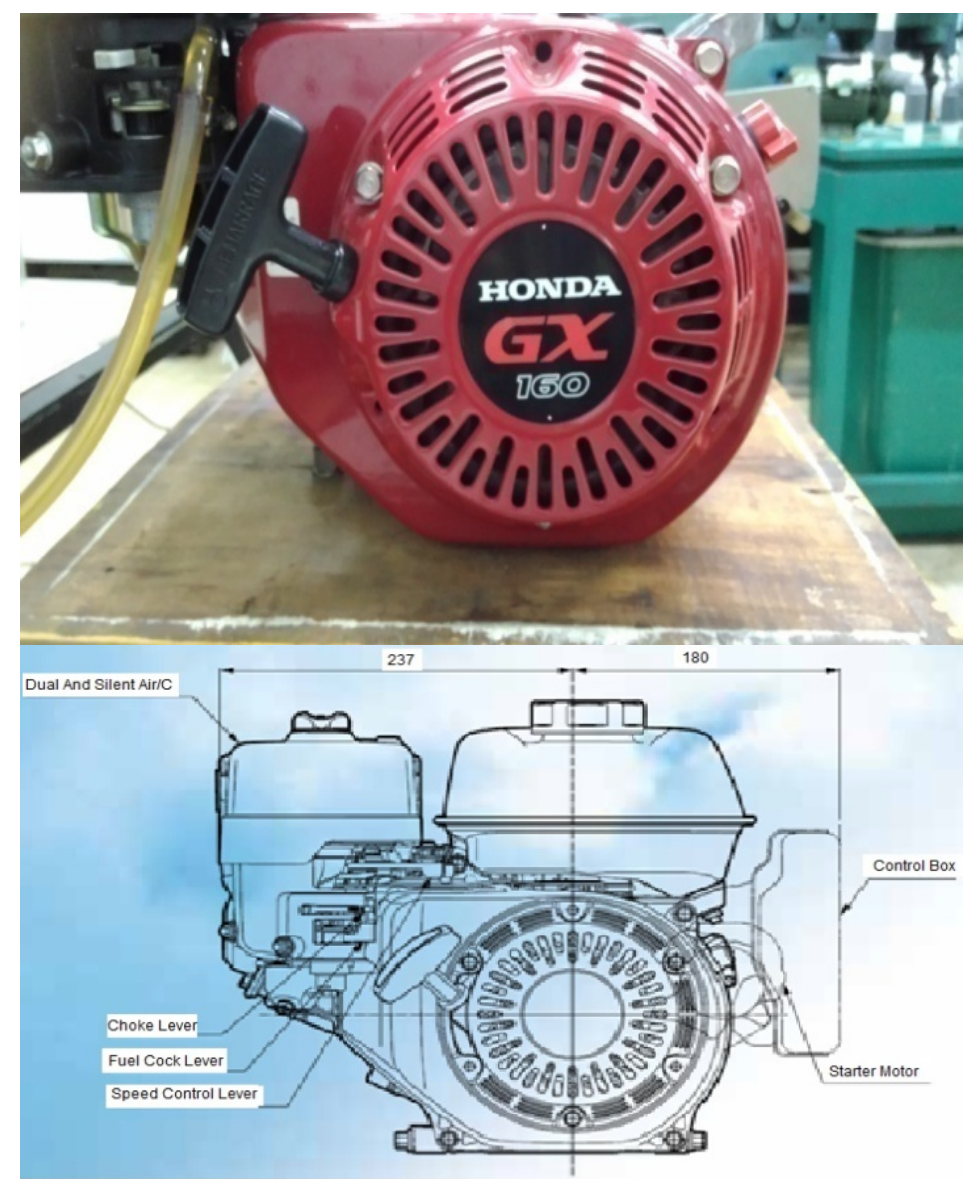

Gambar 4. Mesin Honda GX 160

Dimana motor bakar empat langkah ini memiliki satu silinder, pendingin udara, dan sistem penyalaan dengan busi (spark ignition) dengan 2 katup. Sistem bahan bakar menggunakan karburator. Motor bakar ini dalam kondisi baik, kemudian dipasang pada bangku uji (test bed) yang dilengkapi dengan alat ukur. Pada percobaan eksperimental ini variabel bebas yang digunakan adalah main jet nosel. Ada tiga variabel bebas yang akan dilakukan pengujian yaitu main jet nosel dari mesin Honda GX 140, Honda GX 160, dan Honda GX 200. Ukuran diameter main jet nosel $\mathrm{GX} 140 \leq \mathrm{GX} 160 \leq \mathrm{GX} 200$.

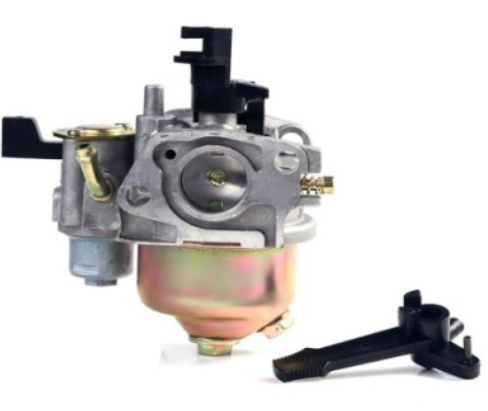

(a)

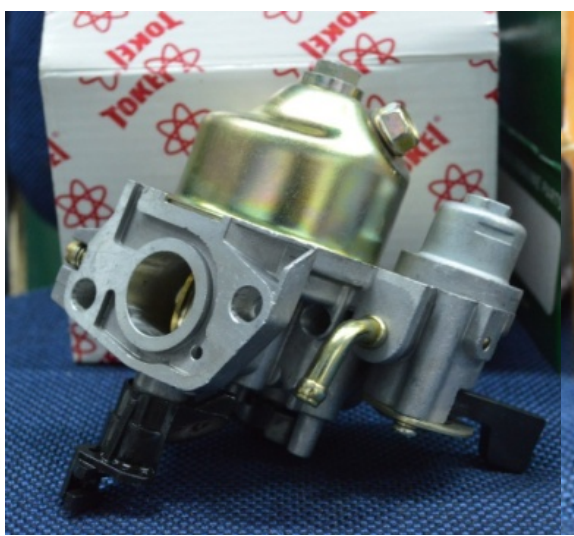

(b)

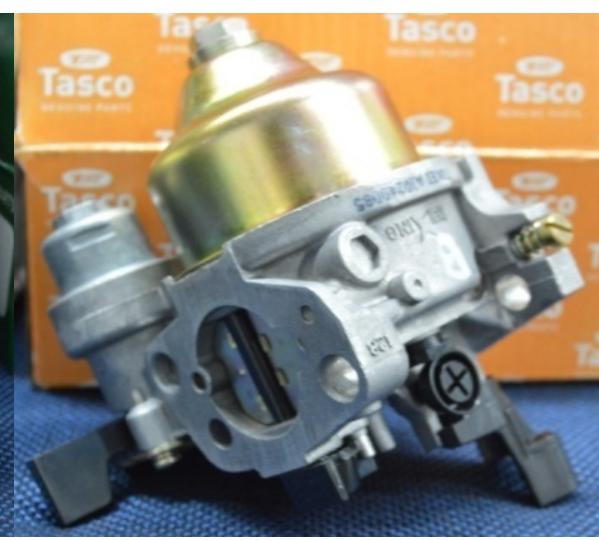

(c)

Gambar 5. (a) Main Jet Nosel Honda GX 160 (b) Main Jet Nosel Honda GX 140 (c) Main Jet Nosel Honda GX 200

Gas analyzer yang digunakan adalah merek Bear, dengan model 42908A 20 dan nomor serial nya adalah 03T0369. Tegangan yang dibutuhkan adalah 230 Volt, dan arus 2 A, kemudian 
frekuensinya $50 \mathrm{~Hz}$. Di dalam eksperimen alat ini digunakan untuk mengukur komponen-komponen yang terdapat di dalam gas buang yaitu $\mathrm{CO}$ (karbon monoksida), $\mathrm{HC}$ sisa (hidrokarbon), $\mathrm{CO}_{2}$ (karbon dioksida), $\mathrm{O}_{2}$ sisa (oksigen), AFR (air-fuel ratio), dan $\lambda$ (lambda).

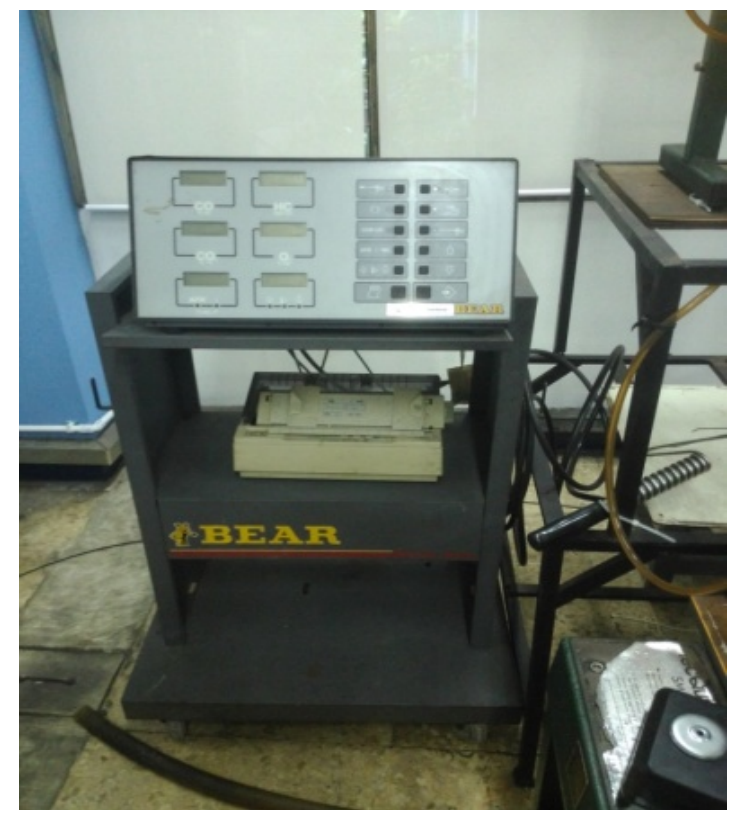

Gambar 6. Bear Exhaust Gas Analyzer

\section{HASIL DAN PEMBAHASAN}

Grafik hasil perhitungan dapat dilihat pada gambar di bawah ini:

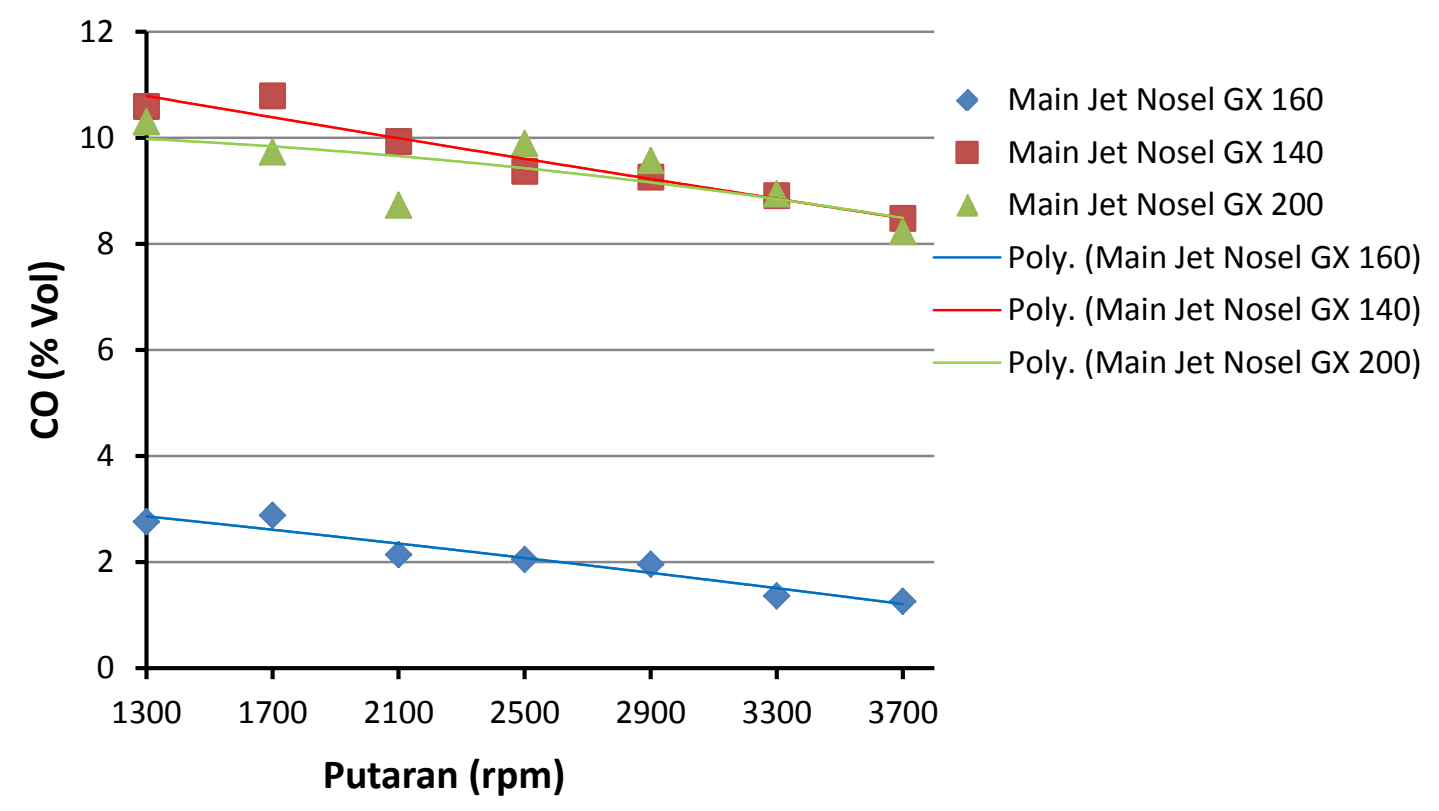

Gambar 7. Grafik CO - Putaran Mesin

Emisi CO yang dihasilkan pada main jet nosel GX 160 merupakan yang paling kecil dibandingkan dua main jet nosel yang lain. Karbon monoksida ini dihasilkan oleh pembakaran yang tidak sempurna, ini dipengaruhi oleh perbandingan campuran bahan bakar dengan udara (air-fuel ratio). Campuran yang semakin kurus (udara berlebih/ excess air) akan menghasilkan CO yang semakin rendah begitu pula sebaliknya. 
Dari tiga main jet semuanya menunjukkan tren nilai CO yang semakin turun untuk putaran yang lebih tinggi. Pada putaran tinggi pembakaran menjadi lebih baik sehingga reaksi pembakaran yang tidak sempurna berupa $\mathrm{CO}$ berubah menjadi pembakaran sempurna yang menghasilkan $\mathrm{CO}_{2}$, pada putaran tinggi udara yang masuk dan tercampur ke dalam motor lebih banyak sehingga menyebabkan kadar campuran bahan bakar dan udara menuju ke campuran yang semakin kurus, sehingga kadar CO bisa turun.

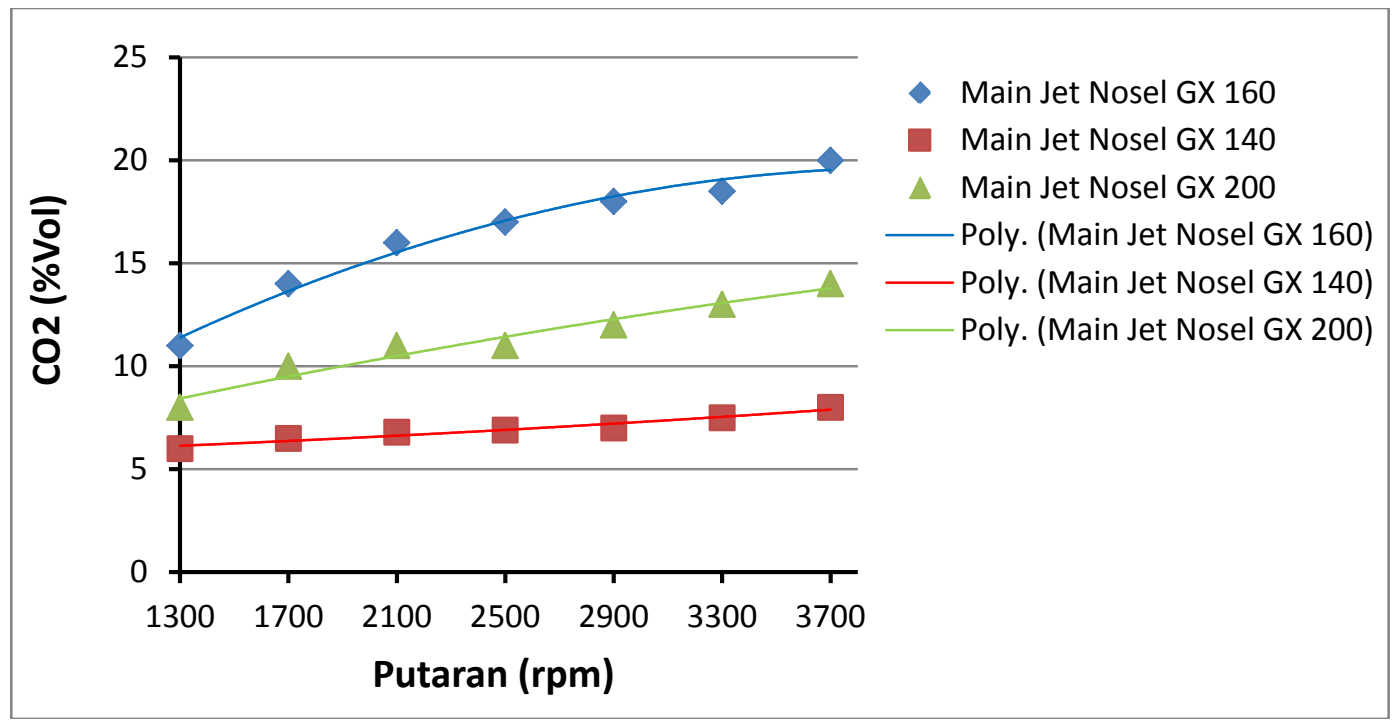

Gambar 8. Grafik $\mathrm{CO}_{2}$ - Putaran Mesin

Emisi $\mathrm{CO}_{2}$ tertinggi keluar dari knalpot gas buang pada main jet nosel GX 160 dan emisi $\mathrm{CO}_{2}$ terendah keluar dari knalpot gas buang pada main jet nosel GX 140. Pada putaran tinggi bahan bakar tercampur dengan baik sehingga gas $\mathrm{CO}_{2}$ yang dikeluarkan juga meningkat. Semakin tinggi kadar $\mathrm{CO}_{2}$ di dalam gas buang artinya pembakaran di ruang bakar tersebut semakin baik dan mendekati pembakaran stoikiometrik.

Untuk main jet nosel GX 140 kadar $\mathrm{CO}_{2}$ yang dihasilkan paling sedikit, karena udara yang masuk kurang mencukupi, ketika main jet nosel diganti dengan ukuran yang berbeda (ukuran yang bukan standar), bisa jadi tekanan udara yang masuk tidak sesuai sehingga mengakibatkan pembakaran di ruang bahan bakar menjadi tidak sempurna, karena udara dengan bahan bakar tidak tercampur dengan baik.

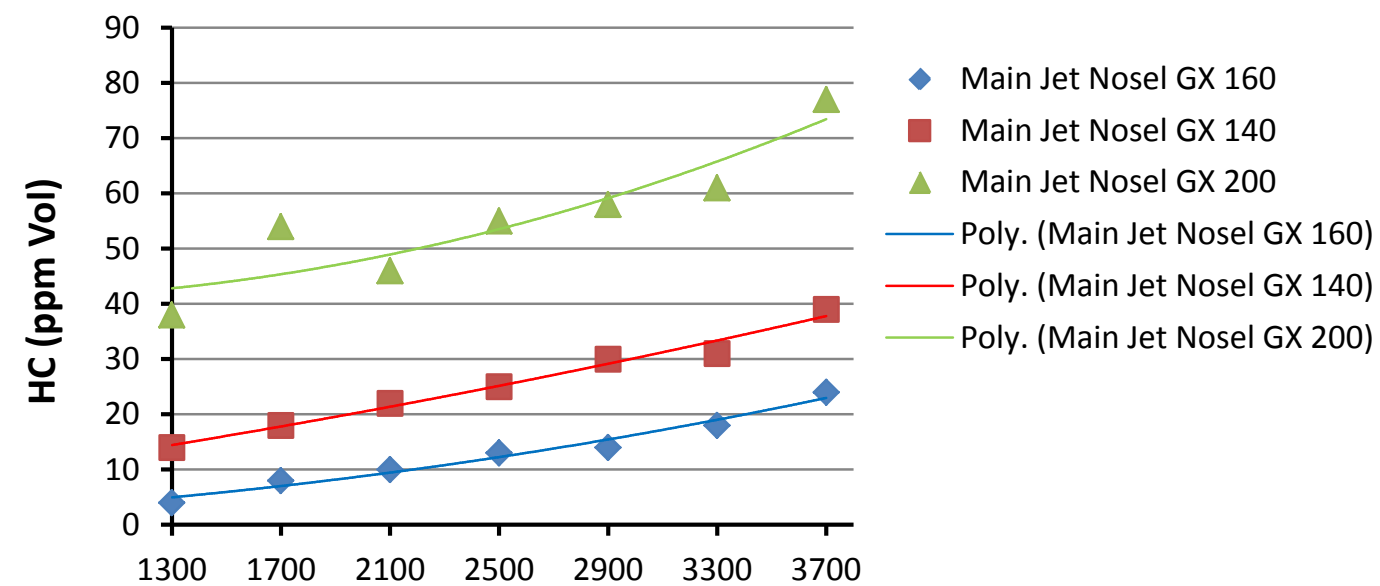

Putaran (rpm)

Gambar 9. Grafik HC - Putaran Mesin 
Semakin tinggi putaran tren yang ditunjukkan HC mengalami kenaikan, artinya pada putaran tinggi semakin banyak bahan bakar yang tidak terbakar. Emisi dari hidrokarbon sisa ini biasa digunakan untuk mengukur seberapa efektif suatu pembakaran. Emisi HC menunjukkan bahwa pembakaran sangat kaya melebihi pembakaran stoikiometrik. HC sisa bisa terbentuk dan teroksidasi pada saat proses langkah kerja ekspansi dan pada saat langkah kerja buang (exhaust). HC tinggi bisa diduga karena ada kerusakan pada mekanis pada dalam mesin seperti pada klep, ring atau silinder.

Pada putaran yang tinggi bahan bakar yang masuk lebih besar sehingga pembakaran semakin kaya, oleh karena pencampuran bahan bakar dan udara menjadi tidak ideal, jumlah bahan bakar lebih banyak sedangkan jumlah oksigen untuk membakarnya kurang, pembakaran menjadi tidak sempurna. HC merupakan sebagian bensin yang tidak terbakar oleh karena itu apabaila kadar HC tinggi berarti tenaga kurang dan konsumsi bahan bakar meningkat.

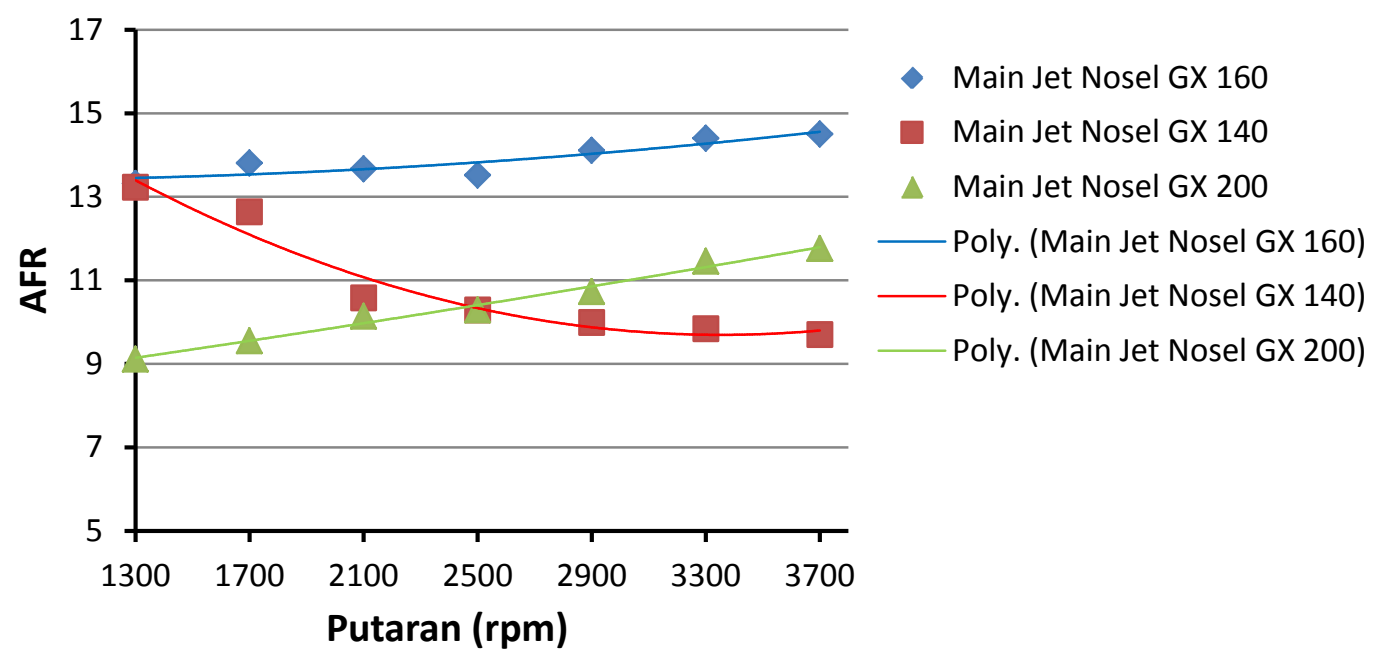

Gambar 10. Grafik AFR - Putaran Mesin

AFR menunjukkan besarnya jumlah udara dibandingkan dengan jumlah kebutuhan bahan bakar. Pada GX 160 AFR meningkat dari 13,32 menjadi 14,5, sedangkan untuk GX 140 turun (campuran makin kaya) dan GX 200 naik (mendekati campuran stoikiometrik). Ini bisa terjadi karena diameter GX 200 lebih besar dari ukuran standar GX 160, maka pada putaran rendah jumlah udara yang masuk ke dalam karburator belum mencukupi, ukuran butir bahan bakar semakin besar maka dibutuhkan udara yang lebih banyak juga.

Main jet nosel GX 200 cocok digunakan untuk putaran tinggi. Sedangkan pada main jet nosel GX 140 pada putaran rendah campuran bahan bakar dengan oksigennya baik, tetapi ketika dipakai untuk putaran yang lebih tinggi ternyata mempengaruhi proses pembakaran, akibatnya pembakaran malah menjauhi stoikiometri. Main jet nosel GX 140 ini lebih cocok digunakan untuk putaran rendah.

Dari Gambar 11, selama proses pengujian eksperimental $\lambda$ (lambda) yang didapat tidak pernah melebihi 1, artinya semua pengujian eksperimental terjadi di dalam campuran kaya bahan bakar, tidak ada excess air. Oleh karena itu $\mathrm{O}_{2}$ sisa tidak terdeteksi, jika ada pun nilainya kecil sekali jadi bisa diabaikan. Dari Gambar 11 dapat dilihat untuk main jet nosel GX 160 kurva mengalami kenaikan, pada saat putaran $1300 \mathrm{rpm} \lambda$ bernilai 0,913 kemudian meningkat pada putaran 3700 rpm menjadi 0,987, ini mendekati kondisi stoikiometrik.

Untuk kurva main jet nosel GX 140 kurva mengalami penurunan, pada saat putaran 1300 $\operatorname{rpm} \lambda$ bernilai 0,901 kemudian pada saat putaran $3700 \mathrm{rpm} \lambda$ bernilai 0,655 . Untuk kurva main jet nosel GX 200 kurva mengalami kenaikan, pada saat putaran $1300 \mathrm{rpm}$ nilai $\lambda$ nya adalah 0,62 
kemudian meningkat pada putaran 3700 rpm menjadi 0,809. Kurva main jet nosel GX 140 dan kurva main jet nosel GX 200 berpotongan di putaran $2500 \mathrm{rpm}$ dengan nilai $\lambda$ sekitar 0,7.

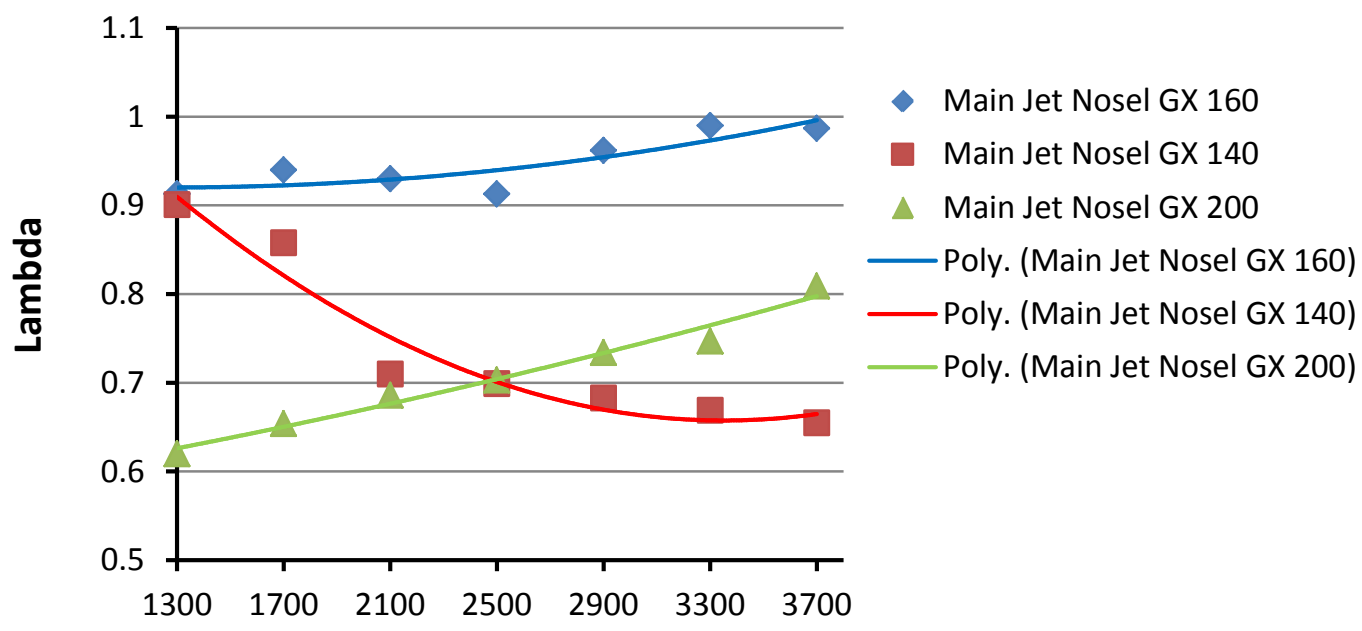

Putaran (rpm)

Gambar 11. Grafik Lambda - Putaran Mesin

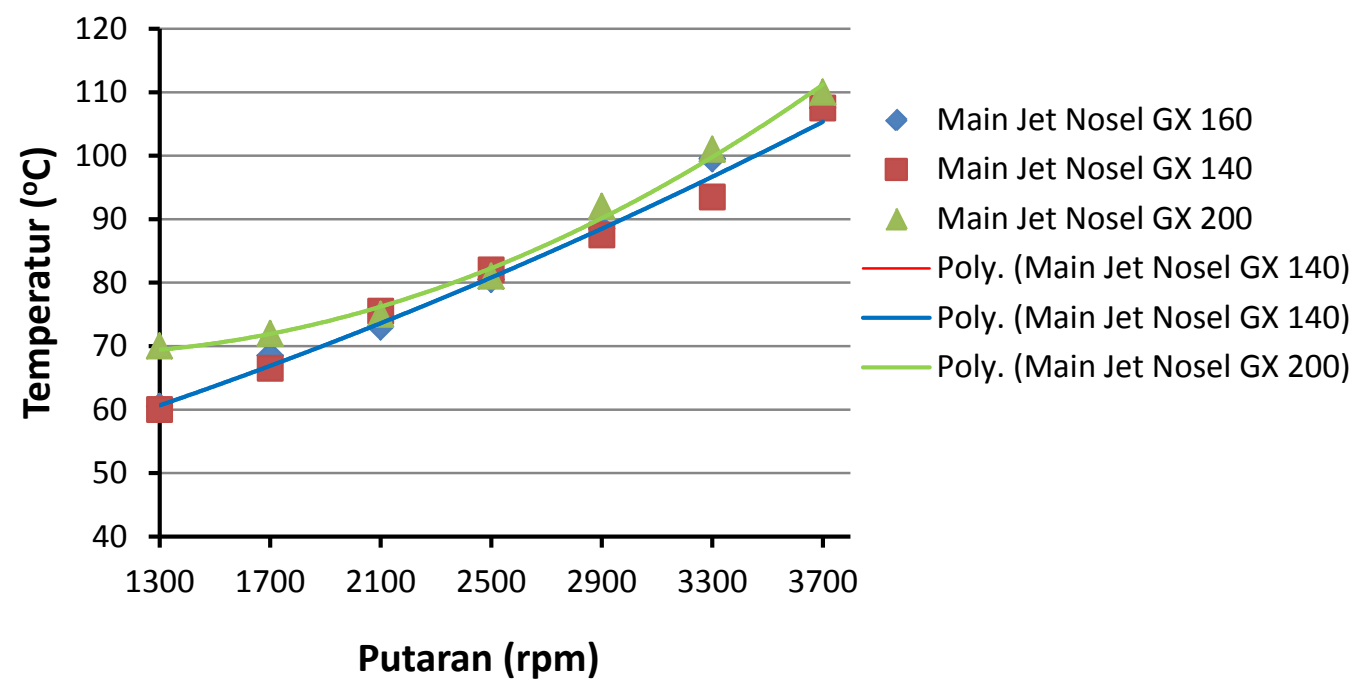

Gambar 12. Grafik Temperatur - Putaran Mesin

Pada putaran 1300 rpm suhu terendah dimiliki main jet nosel GX 140 dan main jet nosel GX 160 (tidak memiliki perbedaan yang jauh) yaitu $60^{\circ} \mathrm{C}$ dan $60,5^{\circ} \mathrm{C}$, pada main jet nosel $\mathrm{GX} 200$ temperaturnya adalah $70^{\circ} \mathrm{C}$. Pembakaran semuanya terjadi pada wilayah miskin udara sehingga temperatur terus mengalami kenaikan, tidak ada $\mathrm{O}_{2}$ sisa, sehingga mesin lebih panas (temperaturnya tinggi). Entalpi dan temperatur adalah berbanding lurus maka ketika entalpi pembakaran yang dikeluarkan semakin besar, temperatur gas buang yang dihasilkan juga akan semakin besar.

Dari gambar grafik analisis HC bisa dilihat pada main jet nosel GX 200, HC sisa yang dikeluarkan sangat besar, maka akibatnya temperatur gas buangnya juga lebih tinggi dibandingkan yang lainnya. Hal ini disebabkan adanya partikel-partikel HC yang bersuhu tinggi tapi belum habis terbakar lolos dari proses ekspansi dan proses exhaust di dalam ruang bakar, sehingga bisa keluar dari knalpot gas buang. Ini mengakibatkan suhu temperatur gas buang bertambah tinggi. 


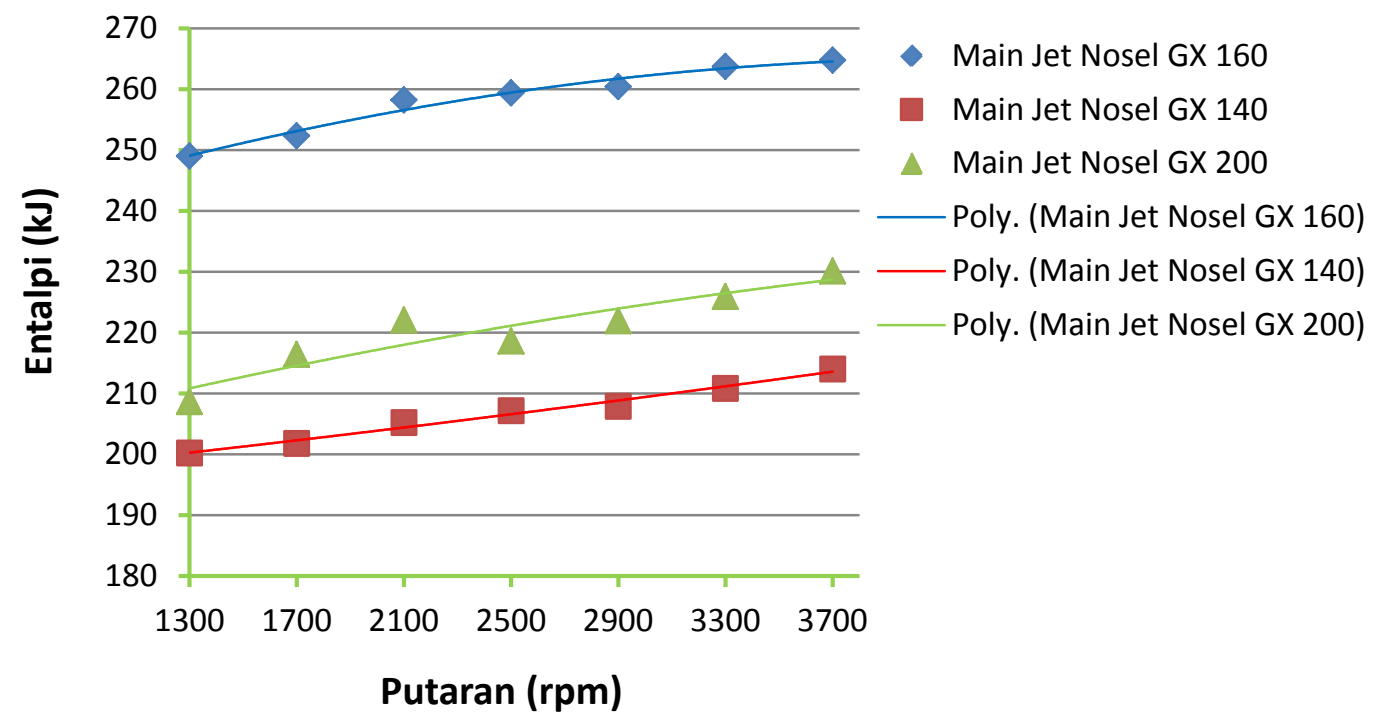

Gambar 13. Grafik Entalpi Pembakaran - Putaran Mesin

Pada putaran 1300 rpm untuk main jet nosel GX 160, entalpi pembakaran yang dikeluarkan adalah 249,01 kJ, sedangkan untuk main jet nosel GX 140 entalpi pembakaran yang dikeluarkan adalah 200,225 kJ, dan untuk main jet nosel GX 200 entalpi pembakarannya adalah 208,63 kJ. Semakin tak sempurna pembakaran maka akan semakin banyak karbon monoksida yang dihasilkan.

Pembakaran tak sempurna menghasilkan lebih sedikit kalor. Kerugian lain dari pembakaran tak sempurna adalah dihasilkannya gas karbon monoksida (CO), yang bersifat racun. Oleh karena itu, pembakaran tak sempurna akan mencemari udara. Main jet nosel GX 160 sudah didesain dari pabrik sesuai dengan kondisi yang ada, maka bisa menghasilkan entalpi pembakaran yang cukup tinggi, lebih tinggi dibandingkan main jet nosel yang lainnya.

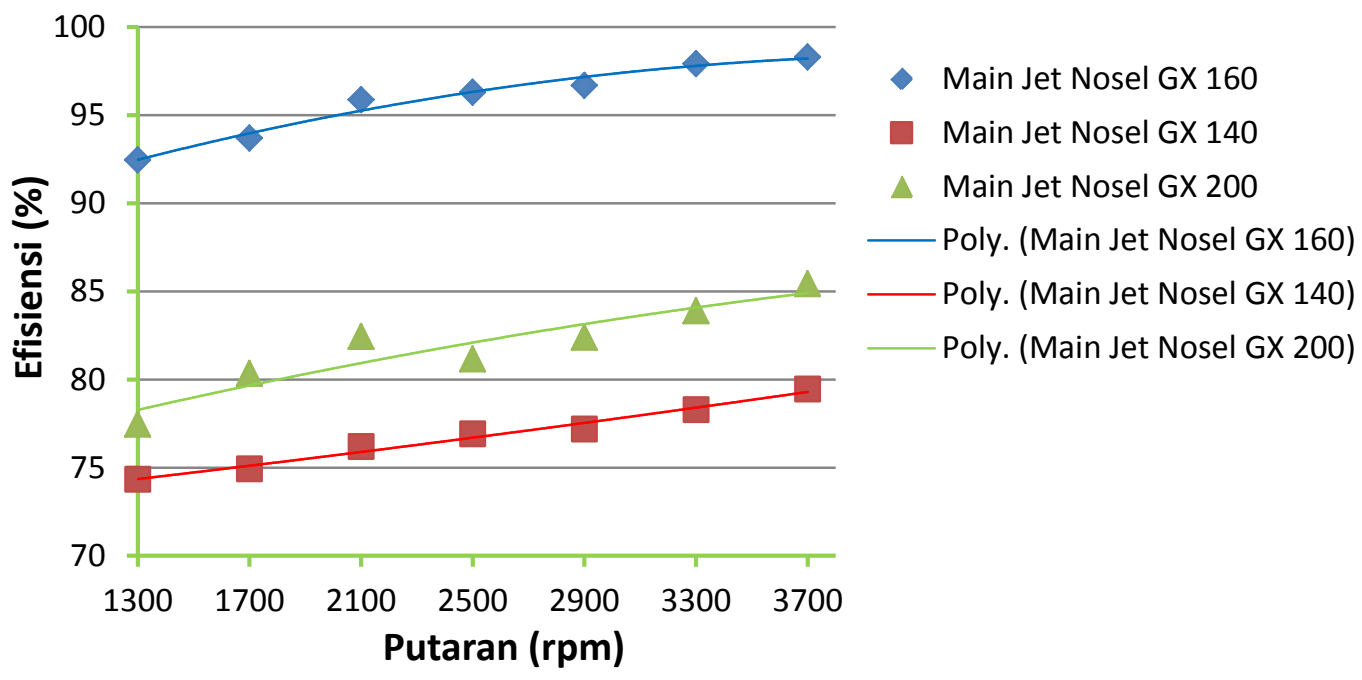

Gambar 14. Grafik Efisiensi Entalpi Pembakaran - Putaran Mesin

Putaran semakin tinggi maka efisiensi entalpi pembakaran juga semakin meningkat, pada putaran 3700 rpm didapat efisiensi tertinggi untuk ketiga main jet nosel, untuk main jet nosel GX 160 didapat efisiensi sebesar 92,45\% untuk main jet nosel GX 140 didapat efisiensi sebesar 79,45\% dan untuk main jet nosel GX 200 didapat efisiensi sebesar 85,43\%.

Dari grafik tersebut terlihat bahwa semakin tidak sempurna suatu pembakaran maka efisiensi entalpi bahan bakarnya akan semakin berkurang, kalor yang dihasilkan menjadi lebih 
sedikit dibandingkan yang seharunya bisa dikeluarkan. Secara garis besar main jet nosel GX 160 memiliki efisiensi entalpi pembakaran 19,95\% lebih tinggi dibandingkan main jet nosel GX 140 dan 14,615\% lebih tinggi dibandingkan main jet nosel GX 200.

\section{KESIMPULAN DAN SARAN}

Dari ketiga main jet nosel, main jet nosel GX 160 (main jet standar) yang didesain dari pabrik mempunyai komposisi gas buang yang paling baik, ini mengacu pada faktor lingkungan. Kadar $\mathrm{CO}_{2}$ lebih tinggi dengan nilai 20\%, kadar $\mathrm{CO}$ lebih rendah dengan nilai $1,26 \%$ dan nilai entalpi pembakarannya paling besar dengan nilai 264.769 kJ. Pembakaran yang terjadi lebih mendekati pembakaran stoikiometrik. Semakin besar $\mathrm{CO}_{2}$ yang dihasilkan maka akan semakin baik suatu pembakaran, mendekati pembakaran yang ideal. Sedangkan jika kadar CO semakin tinggi maka pembakaran yang terjadi semakin tidak sempurna. Dengan melihat komposisi gas buang maka unjuk kerja suatu mesin bisa diketahui. Untuk penelitian selanjutnya bisa dengan mengganti bahan bakar atau menambah zat aditif untuk dianalisis komposisi gas buangnya dan diketahui karakteristik emisinya. Gas analyzer yang digunakan juga yang lebih baik sehingga bisa mendeteksi NOx dan SOx.

\section{DAFTAR PUSTAKA}

[1]. Karnowo, Sunyoto, dkk. Teknik Mesin Industri. Jakarta: Departemen Pendidikan Nasional, 2008.

[2]. I Gede Wiratmaja. ANALISA UNJUK KERJA MOTOR BENSIN AKIBAT PEMAKAIAN BIOGASOLINE. Cakram. Vol. 4 No.1 (April 2010): 16-25.

[3]. Jama, Jalius, dkk. Teknik Sepeda Motor. Jakarta: Departemen Pendidikan Nasional, 2008.

[4]. Ganesan, V. Internal Combustion Engines $2^{\text {nd }}$ ed. Singapore: McGraw-Hill Book Co., 2003.

[5]. Obert, Edward F. Internal Combustion Engines, third edition. Pennsylvania: International Textbook Company, 1968.

[6]. Pulkabrek, William W. Engineering Fundamental of The Internal Combustion Engine. New Jersey: Prentice-Hall, Inc., 1997.

[7]. Awal Syahrini. ANALISA KINERJA MESIN BENSIN BERDASARKAN HASIL UJI EMISI. SMARTek . Vol.4 No.4 (November 2006): 260-266

[8]. Sharma, S.P. Fuels and Combustion. India: McGraw, 1984.

[9]. Isnanda. PENGARUH GAS BUANG TERHADAP KINERJA MOTOR BENSIN. Jurnal Teknik Mesin. Vol. 4 No.1 (Juni 2007): 62-67

[10]. Borgnakke, Claus. Fundamental of Thermodynamics SI Version $7^{\text {th }}$ ed. United States: John Wiley \& Sons (Asia), 2009.

[11]. Heywood, John B. Internal Combustion Engine Fundamentals. United States: McGraw-Hill, Inc., 1988. 